\title{
Bioorganic studies on the venom from duckbill platypus*
}

\author{
Masaki Kita $\ddagger$ \\ Graduate School of Pure and Applied Sciences, University of Tsukuba, \\ 1-1-1 Tennodai, Tsukuba, Ibaraki 305-8571, Japan
}

\begin{abstract}
Venomous mammals are rare, and only a few species in the orders Insectivora and Monotremata produce toxic venom. Among them, the duckbill platypus (Ornithorhynchus anatinus) is one of the two venomous Australian mammals. The adult male platypus carries a spur on each hind leg, which it uses to inject competitors with poison. However, the structure and function of the poison's active compounds are still imcompletely characterized. We found that crude platypus venom produced potent $\mathrm{Ca}^{2+}$ influx in human neuroblastoma IMR-32 cells. Guided by this assay, we identified 11 unique peptides, including peptide H-His-Asp-His-Pro-Asn-Pro-Arg-OH, which coincided with the N-terminal domain residues of Ornithorhynchus venom C-type natriuretic peptide (OvCNP). This heptapeptide induced a significant increase in $\left[\mathrm{Ca}^{2+}\right]_{i}$ in IMR-32 cells at $75 \mu \mathrm{M}$; had relatively specific affinities for glutamate, histamine, and $\mathrm{GABA}_{\mathrm{A}}$ receptors; and facilitated neurogenic twitching in guinea pig ileum specimens at $30 \mu \mathrm{M}$. We also established that its proteinous venom fraction strongly hydrolyzed Pro-Phe-Arg-MCA and cleaved a human low-molecularweight kininogen (LK), similar to porcine pancreas kallikrein. These results strongly indicated that platypus venom contains tissue kallikrein-like protease(s), and its proteolytic activity might synergistically contribute to toxicity through the specific cleavage of other venom constituents.
\end{abstract}

Keywords: bioactive molecules; chemical ecology; mass spectrometry; mammalian venom; natural products.

\section{INTRODUCTION}

Many toxic constituents from lower animals, such as insects, lizards, and snakes, have been well characterized. However, venomous mammals are quite rare, and only a few species, such as shrews and the solenodon (Insectivora), as well as the duckbill platypus (Monotremata), are known to produce toxic venom [1]. Since the disappearance of dinosaurs ( 65 million years ago), these venomous mammals are believed to have evolved with little change in morphology. Interestingly, among living mammals, only these most ancient species produce toxic venom. Thus, identification of the unique bioactive substances in mammalian venoms should help to clarify their evolutional properties and ecological roles. Owing to their instability as well as the difficulty of collecting fresh venom fluid or venomous gland specimens in sufficiently large amounts, mammalian venoms have not been well characterized. However, now that the recent advancements in spectroscopic analyses and genetic approaches are available, we have sought to isolate scarce, unstable, and composite toxic substances of mammalian origin.

*Pure Appl. Chem. 84, 1297-1478 (2012). A collection of invited papers based on presentations at the $27^{\text {th }}$ International Symposium on the Chemistry of Natural Products and the $7^{\text {th }}$ International Conference on Biodiversity (ISCNP-27 \& ICOB-7), Brisbane, Australia, 10-15 July 2011.

\#E-mail: mkita@chem.tsukuba.ac.jp 
Shrews have both the smallest size and the highest metabolic rates among mammals. Venomous shrews are known to not only eat worms and insects, but also to attack vertebrates, even larger than themselves [2]. For example, the short-tailed shrew Blarina brevicauda feeds on murid rodents and frogs [3-5]. The semi-aquatic shrew Neomys fodiens feeds on frogs, newts, and small fish. Therefore, these shrew species may use venom to effectively catch and immobilize large prey to meet their own high metabolic demands [6,7]. We previously identified blarina toxin (BLTX), lethal venom with a tissue kallikrein-like activity, from the salivary glands of $B$. brevicauda. Mice that were administered BLTX i.p. developed irregular respiration, paralysis, and convulsions before dying [8-10]. Homology modeling studies of BLTX revealed that most of the amino acid residues in BLTX highly overlapped those of human tissue kallikrein, including presumed catalytic site residues [11,12].

Meanwhile, the duckbill platypus, Ornithorhynchus anatinus, is one of the two venomous Australian mammals (Fig. 1) [13]. The adult male platypus carries a spur on each hind leg, which it uses to inject competitors with poison. Envenoming by a platypus causes immediate, excruciating pain in humans, which evolves toward a long-lasting hyperalgesia (hypersensitivity to pain). Since the end of the $19^{\text {th }}$ century, several constituents of the platypus venom fluid or its crural gland have been identified [14-16]. Recently, several Australian chemists and biologists have made special efforts to identify and characterize the unique venom constituents [17-19]. They include defensin-like peptides [20-23], C-type natriuretic peptides (OvCNPs) [24-26], nerve growth factor (NGF), and hyaluronidase. In addition, an L-to-D-peptide isomerase has been identified, by which D-Leu ${ }^{2}$ in OvCNPs and D-Met ${ }^{2}$ in defensins are formed [27-30]. While this platypus peptide isomerase was the first identified one of mammalian origin, it was recently shown that this enzyme is also contained in mouse heart and echidna venom $[31,32]$. However, the specific neurotoxic substances in platypus venom that lead to excruciating pain are still incompletely characterized.

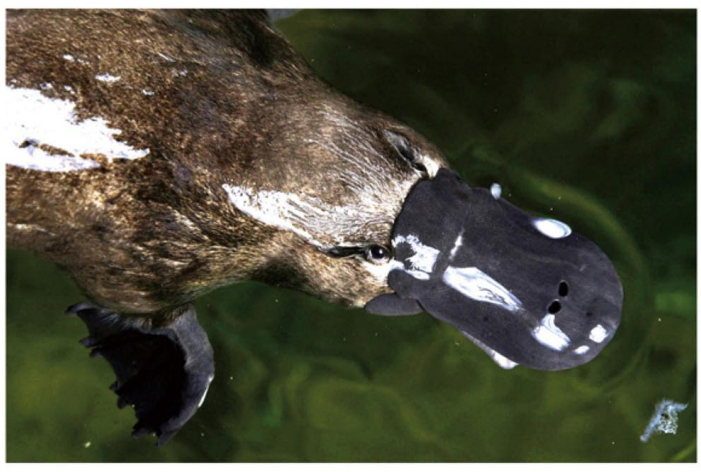

Duckbill platypus

Ornithorhynchus anatinus (Shaw, 1799)

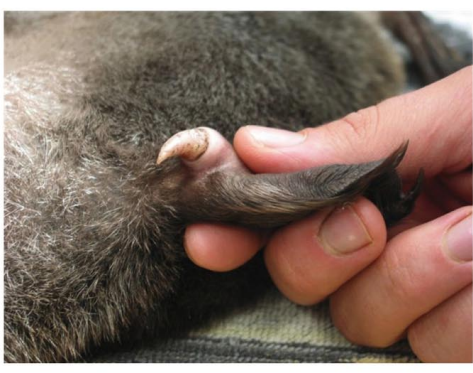

Venomous spur

Fig. 1 Duckbill platypus and its venom apparatus (photo credit: left, Taronga Zoo; right, Dr. Vogelnest).

In 2008 , the platypus genome project was completed. It revealed that the platypus genome consists of 18500 protein-coding genes, and shows reptilian, avian, and mammalian features [33,34]. Various "blueprints of life" have been unveiled in animals ranging from insects to humans. However, to clarify complex and dynamic living systems, it is essential that we investigate the structures and functions of the true bioactive molecules in venom systems.

As mentioned in the previous reviews, we have focused on the identification of natural key compounds that control biologically and physiologically intriguing phenomena [35-39]. Recently, we had the opportunity to obtain fresh platypus venom, with the kind cooperation of Taronga Zoo, Sydney, Australia, and identified picomole amounts of several unique peptides in this venom fluid [40]. This 
review discusses the identification, biological activities, and biosynthesis of these peptides, as well as an investigation of the proteinous components in platypus venom.

\section{RESULTS AND DISCUSSION}

\section{Identification and structures of peptides in platypus venom}

With fresh platypus venom fluid in hand, various bioassays were carried out. Intravenous or intracerebral administration in mice did not produce any significant symptoms, and no hemolytic activity was observed against rabbit or sheep red blood cells. However, the venom produced potent $\mathrm{Ca}^{2+}$ influx in human neuroblastoma IMR-32 cells [11]. Notably, unlike the rapid temporary increase in $\left[\mathrm{Ca}^{2+}\right]_{i}$ (internal calcium ion) caused by $\mathrm{KCl}$, the calcium uptake caused by $\mathbf{1}$ was slow and continuous. Thus, we anticipated that platypus venom might contain some physiologically important neurotoxic substances.

Since platypus venom contains molecules of various sizes, we first chose gel-permeation high-performance liquid chromatography (HPLC) for purification, and the lower-molecular-weight components, fraction IX (discussed below), showed $\mathrm{Ca}^{2+}$ influx activity. Further purification by reverse phase HPLC gave peptide 1 as a primary component ( $200 \mathrm{ng} / \mu \mathrm{L}$ venom fluid) (Fig. 2) [41]. Through the use of matrix-assisted laser desorption/ionization with time-of-flight mass spectrometry (MALDI-TOF/TOF MS) analysis, the primary structure of $\mathbf{1}$ was established to be H-His-Asp-His-Pro-Asn-Pro-Arg-OH, which coincided with the N-terminal domain residues of platypus CNP [40]. CNPs are vasorelaxant peptide hormones that are widely expressed in vivo, including the central nervous system [42]. OvCNPs cause the relaxation of rat uterine smooth muscle, promote histamine release from mast cells, and form fast cation channels in lipid bilayers [24,43-45]. This is the first example of the isolation of N-terminal domain residues of CNPs in any mammal.

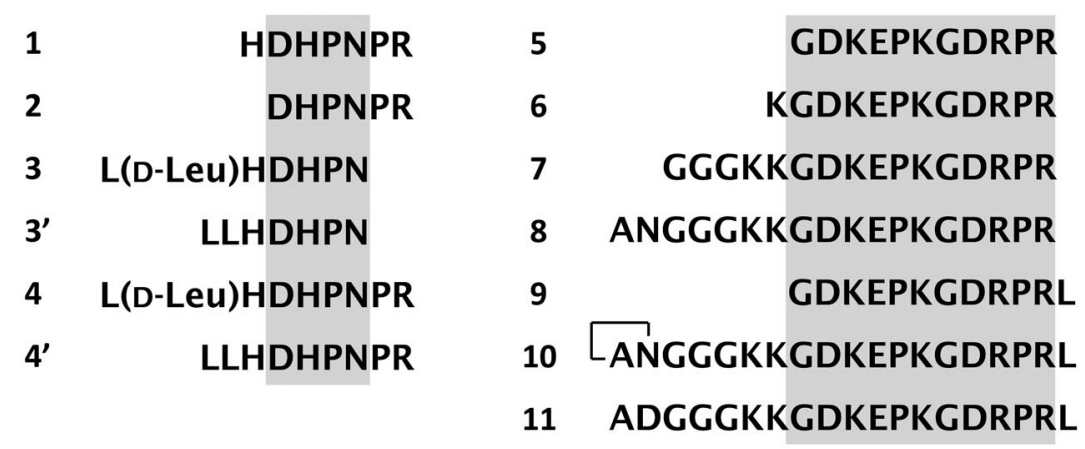

Fig. 2 Amino acid sequences of platypus venom peptides. Common sequences in the N-terminal domain CNP fragment peptides 1-4 and the CNP precursor fragment peptides 5-11 are highlighted.

Furthermore, direct HPLC purification of crude platypus venom afforded peptides $\mathbf{3}$ and $\mathbf{4}$ as major constituents [46]. By comparing the retention times of synthetic and natural peptides, we confirmed that the $\mathrm{Leu}^{2}$ residues in both peptides were of the D-form. Furthermore, a hexapeptide 2, peptides 5-8, and peptides 9-11 were purified from the fr. VI as major constituents. Peptides 2-4 were analogs of 1, which coincided with the 6-9 N-terminal domain residues of OvCNP. Meanwhile, peptides 5-9 corresponded to the 132-150 part of OvCNP precursor peptide (pre-OvCNP). The y-ion fragment patterns in MS/MS data suggested that the $12 \mathrm{C}$-terminal residues in peptides $\mathbf{1 0}$ and $\mathbf{1 1}$ were identical to those in $\mathbf{9}$, but their molecular mass units were 17 less and 1 more than those of pre-OvCNP (132-150), respectively. Further detailed MS/MS analysis revealed that $\mathbf{1 0}$ had a cyclic amide structure 


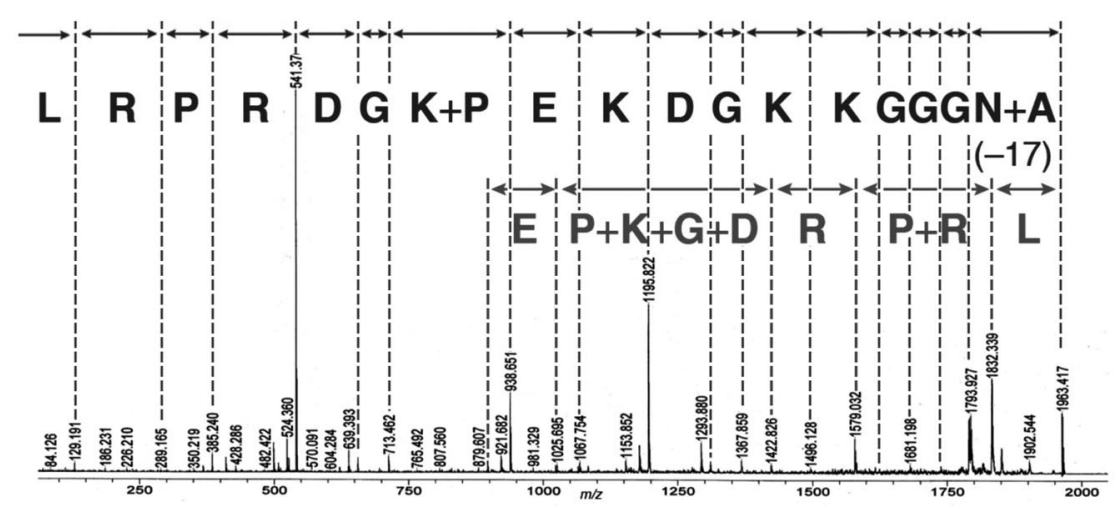

Fig. 3 MALDI-TOF/TOF MS analysis of natural 10 [precursor ion: $1963.4(\mathrm{M}+\mathrm{H})^{+}$]. Observed fragment y-ion peaks cleaved from the $\mathrm{C}$-terminus and b-ion peaks from the $\mathrm{N}$-terminus are denoted in the upper and lower lanes, respectively. The order of $\mathrm{P}+\mathrm{K}$ (proline and lysine) could not be experimentally determined owing to the relatively resistance to the fragmentation of proline peptide bonds. This was estimated from the genome sequence of preOvCNP.

at the N-terminal Ala $1-\mathrm{Asn}^{2}$ moiety by deamidation (Fig. 3) [47], while the amide moiety of the Asn ${ }^{2}$ residue was hydrolyzed to an Asp residue in $\mathbf{1 1}$.

\section{Biological activities of peptides in platypus venom}

Synthetic heptapeptide 1 showed significant $\mathrm{Ca}^{2+}$ influx activity in IMR-32 cells at $75 \mu \mathrm{M}$ [40]. Unlike the fast and temporary increase in $\left[\mathrm{Ca}^{2+}\right]_{i}$ caused by $\mathrm{KCl}$, the calcium uptake caused by $\mathbf{1}$ was slow and continuous, which was identical to the result with crude venom. In addition, among peptides 1-9, only heptapeptide 1 produced prominent inflammation (s.c. injection, $1 \mathrm{mg}$ per $10 \mathrm{~g}$ mice) and shaking behavior (intracerebral injection, idem) [48,49].

We used differentiated IMR-32 cells that expressed L- and N-type voltage-gated calcium channels (VGCCs). Based on the results of various receptor-binding assays, however, heptapeptide 1 did not significantly bind to L- or N-type VGCCs, potassium channels $\left(\mathrm{K}_{\mathrm{A}}\right.$ and $\mathrm{K}_{\mathrm{ATP}}$, hERG), or a sodium channel (site 2) at $10 \mu \mathrm{M}$ (Table 1). These results suggested that the venom peptide 1 may not directly activate known voltage-gated ion channels, but may specifically bind to other receptor channels or biomacromolecules. Indeed, among the various receptors tested that are related to pain, inflammation, or neurotransmission, $\mathbf{1}$ had relatively specific affinities for glutamate, histamine $\mathrm{H}_{1}$, and $\mathrm{GABA}_{\mathrm{A}}$ receptors. 
Table 1 Receptor binding assays of peptide 1.

\begin{tabular}{|c|c|}
\hline Receptor & Inhibition $(\%)$ \\
\hline Adrenergic $\alpha_{1}$ & 6 \\
\hline Adrenergic $\alpha_{2}$ & 3 \\
\hline Adrenergic $\beta$ & -3 \\
\hline Bradykinin $\mathrm{B}_{1}$ & -8 \\
\hline Bradykinin $\mathrm{B}_{2}$ & -5 \\
\hline Calcium channel L-type, benzothiazepine & -16 \\
\hline Calcium channel L-type, dihydropyridine & 4 \\
\hline Calcium channel L-type, phenylalkylamine & -17 \\
\hline Calcium channel N-type & 1 \\
\hline Cannabioid $\mathrm{CB}_{1}$ & -1 \\
\hline Cannabioid $\mathrm{CB}_{2}$ & -10 \\
\hline Chemokine CCR1 & 4 \\
\hline Chemokine CXCR1/2 & 2 \\
\hline Cholecystokinin $\mathrm{CCK}_{2}$ & 5 \\
\hline Dopamine $\mathrm{D}_{1}$ & -14 \\
\hline Dopamine $\mathrm{D}_{2 \mathrm{~L}}$ & 4 \\
\hline $\mathrm{GABA}_{\mathrm{A}}$, chloride channel, TBOB & 3 \\
\hline $\mathrm{GABA}_{\mathrm{A}}$, flunitrazepam, Central & 21 \\
\hline $\mathrm{GABA}_{\mathrm{A}}$, muscimol, central & 9 \\
\hline Glutamate, kainate & 16 \\
\hline Glutamate, NMDA, phencyclidine & 0 \\
\hline Histamine $\mathrm{H}_{1}$ & 11 \\
\hline Neuropeptide Y Y 1 & -7 \\
\hline Neurotensin & 0 \\
\hline Nicotinic acetylcholine $\alpha_{1}$, bungarotoxin & -5 \\
\hline Opiate $\delta(\mathrm{OP} 1, \mathrm{DOP})$ & -15 \\
\hline Opiate $\kappa(\mathrm{OP} 2, \mathrm{KOP})$ & 4 \\
\hline Opiate $\mu(\mathrm{OP} 3, \mathrm{MOP})$ & 1 \\
\hline Orphanin $\mathrm{ORL}_{1}$ & 8 \\
\hline Potassium channel $\left[\mathrm{K}_{\mathrm{A}}\right]$ & 1 \\
\hline Potassium channel $\left[\mathrm{K}_{\mathrm{ATP}}\right]$ & -3 \\
\hline Potassium channel hERG & -14 \\
\hline Serotonin $5-\mathrm{HT}_{1}$ & -12 \\
\hline Serotonin $5-\mathrm{HT}_{2}$ & -8 \\
\hline Sodium channel site 2 & -12 \\
\hline Tachykinin $\mathrm{NK}_{1}$ & -16 \\
\hline Vanilloid & -2 \\
\hline
\end{tabular}

Substrate concentration $=10 \mu \mathrm{M}$.

Next, we compared the receptor antagonism activities of $\mathbf{1}$ and its analogs $\mathbf{3}, \mathbf{4}$, and $\mathbf{4}$ ' (an L-Leu ${ }^{2}$ analog of 4) for the selected receptors described above (Fig. 4). Among glutamate receptors, while natural peptides $\mathbf{1}, \mathbf{3}$, and $\mathbf{4}$ all bound similarly to kainate-type receptors, different affinities were observed for NMDA-type. It is interesting how these binding specificities can be linked to the neurotoxicity of $\mathbf{1}$ or kainic acid in mice. Furthermore, heptapeptide $\mathbf{1}$ facilitated a neurogenic twitching in guinea pig ileum specimens at $30 \mu \mathrm{M}$. Thus, compound $\mathbf{1}$ was found to have agonist activity at histamine $\mathrm{H}_{1}$ or $\mathrm{GABA}_{\mathrm{A}}$ receptors, which might be related to its inflammatory activity in mice. 


\begin{tabular}{|c|c|c|c|c|c|c|c|c|c|}
\hline & \multicolumn{4}{|c|}{ Peptides } & & \multicolumn{4}{|c|}{ Peptides } \\
\hline & 1 & 3 & 4 & $4^{\prime}$ & & 1 & 3 & 4 & $4^{\prime}$ \\
\hline $\begin{array}{l}\text { Glutamate, Kainate } \\
\left({ }^{[} \mathrm{H}\right] \text { kainic acid) }\end{array}$ & 16 & 12 & 21 & 2 & $\begin{array}{l}\text { Glutamate, AMPA } \\
\left({ }^{3} \mathrm{H}\right] \text { AMPA) }\end{array}$ & 1 & 5 & 8 & ND \\
\hline $\begin{array}{l}\text { Glutamate, NMDA, } \\
\left.\text { glycine }\left({ }^{3} \mathrm{H}\right] \mathrm{MDL}-105519\right)\end{array}$ & 18 & -1 & -5 & 0 & $\begin{array}{l}\text { Histamine } \mathbf{H}_{1} \\
\left.\left.\text { ([}{ }^{3} \mathrm{H}\right] \text { pyrilamine }\right)\end{array}$ & 11 & 10 & 5 & 13 \\
\hline $\begin{array}{l}\text { Glutamate, NMDA, } \\
\text { agonism }\left(\left[{ }^{3} \mathrm{H}\right] \text { CGP-39653) }\right.\end{array}$ & -1 & -4 & 21 & 27 & $\begin{array}{l}\mathrm{GABA}_{\mathbf{A}} \\
\text { ([3H] flunitazepam) }\end{array}$ & 21 & 16 & 1 & 2 \\
\hline
\end{tabular}

Fig. 4 Receptor antagonism assays of platypus CNP fragment peptides. Substrate concentration $=10 \mu \mathrm{M}$. Values of the inhibitory effects $(\%)$ are shown in the bar graph. $\mathrm{ND}=$ no data.

\section{Protease activity and SDS-PAGE analysis of platypus venom}

Since the C-termini of several platypus venom peptides, $\mathbf{1}, \mathbf{2}$, and 4-8, were free arginine residues (Fig. 2), we anticipated that platypus venom had trypsin or kallikrein-like protease activity. Indeed, a proteinous venom fraction, especially fr. II, strongly hydrolyzed Pro-Phe-Arg-MCA, a fluorescent peptide substrate of tissue kallikrein (Fig. 5a).

a)

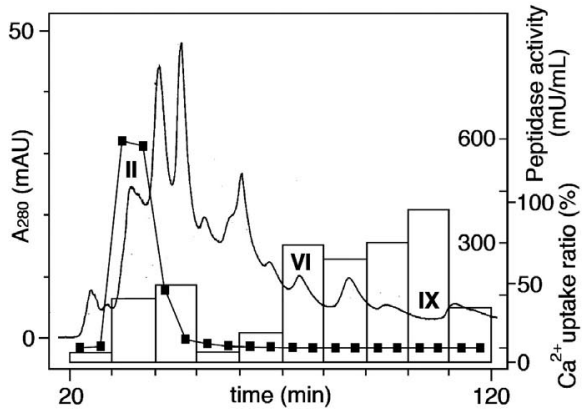

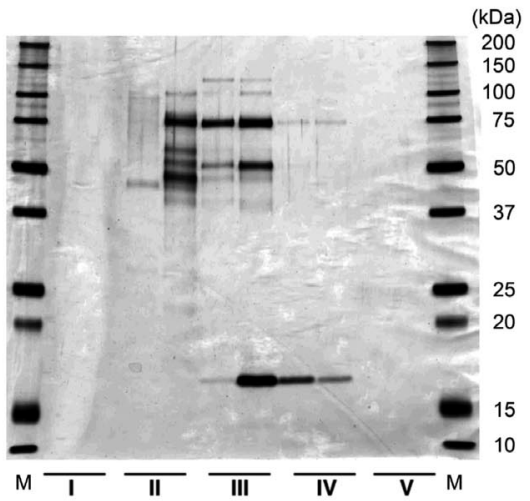

Fig. 5 Purification of the proteins in platypus venom. (a) Gel-permeation HPLC of venom fluid $(5 \mu \mathrm{L})$. The effect

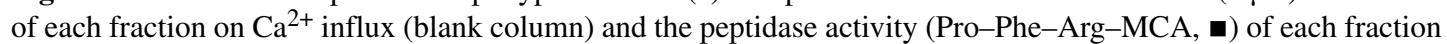
are shown. (b) SDS-PAGE analysis of the proteins in platypus venom. Fr. I-V (1/100 amount) was loaded and proteins were detected by silver staining.

We also examined the in vitro kininogen cleavage activities of platypus venom. On sodium dodecyl sulfate-polyacrylamide gel electrophoresis (SDS-PAGE) analysis, fr. II degraded a human lowmolecular-weight kininogen (LK) in a time-dependent manner (Fig. 6a). The degradation products resulting from incubation with fr. II appeared to be identical to those obtained by incubation with porcine pancreatic kallikrein (PPK). Furthermore, these degradations were markedly suppressed by the serine protease inhibitor aprotinin (bovine pancreatic trypsin inhibitor). These observations strongly indicated that platypus venom contains tissue kallikrein-like protease(s).

Tissue kallikrein (EC 3.4.21.35) cleaves diverse polypeptide precursors such as kininogens, epidermal growth factor, NGF, and angiotensinogen, and also liberates biologically active peptides in vitro [50]. This enzyme is uniquely characterized by its ability to hydrolyze two specific and distinct peptide 
a)

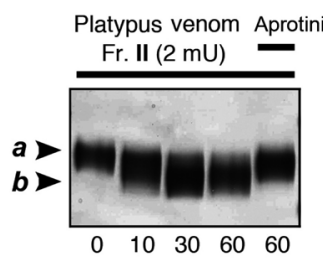

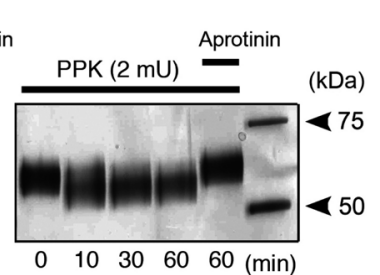

b)

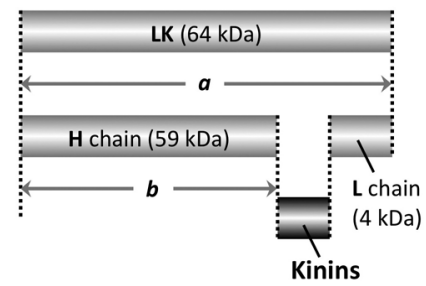

Fig. 6 Kininogen cleavage activity of platypus venom. (a) SDS-PAGE analysis of the degradation of LK by fr. II or PPK at various time intervals, and its inhibition by aprotinin $(10 \mu \mathrm{M})$. Band $a$, LK $(64 \mathrm{kDa})$; band $b$, degraded products $(59 \mathrm{kDa})$. (b) Schematic representation of the hydrolysis and resulting fragmentation of LK.

bonds, Met-Lys (human) or Lys-Arg (mouse), and Arg-Ser (all mammals), within kininogens to release lysyl-bradykinin (kallidin) or bradykinin (BK), respectively (Fig. 6b). Liberated kinins potently relax vascular smooth muscle, increase vasodilation, and enhance vascular permeability [51,52]. Thus, it has been suggested that the kallikrein-kinin system may play an important role in blood pressure homeostasis and pain. It was found that the lethal venom of Blarina shrew, BLTX, converts kininogens to kinins. Furthermore, both the acute toxicity in mice and proteolytic activity of BLTX are strongly inhibited by aprotinin, which suggests that its toxicity is due to a kallikrein-like activity of the venom $[8,9]$. Several kallikrein-related proteases, including gila toxin (GTX) and horridum toxin (HTX), have been isolated as lethal factors from lizards [53,54]. Both of these toxins have hypotensive effects when injected into rats, and are also hemorrhagic, yet only HTX causes exophthalmia (protrusion of the eyes) [55]. While platypus venom is not lethal in mice, it is interesting that all of these venomous vertebrates produce and use such similar secretory serine proteases.

In an SDS-PAGE analysis of the higher-molecular-weight components of platypus venom, several proteins were detected between fr. II-IV (Fig. 5b). It was established that by the detailed MS/MS analysis of the tryptic peptide fragments obtained by an in-gel digestion, two major proteins in fr. III were $\alpha$-trypsin inhibitor $\left(\alpha_{1} \mathrm{TI}, 51 \mathrm{kDa}\right)$ and lactoferrin $(80 \mathrm{kDa})$, respectively [56]. Meanwhile, kallikrein-like protease(s) were present in very minute amounts, and have not yet been identified, but might correspond to a single $48-\mathrm{kDa}$ band of the first half of fr. II.

A cDNA library from its venom gland was constructed by the researchers who decoded the platypus genome [57]. Based on its transcriptome data, 83 putative platypus venom peptides/proteins in 13 different families were identified, and interestingly, the largest group consisted of serine proteases. Most recently, gene duplications and the expression of transcripts were analyzed in an in-season platypus venom gland, which included several serine proteases, metalloproteinases, and protease inhibitors [58]. It was noteworthy that serine proteases (kallikrein and other) and Kunitz-type protease inhibitors $\left(\alpha_{1}\right.$ TI $)$, which are likely to produce symptoms associated with envenomation such as vasodilation and pain, were found to be contained in platypus venom based on both gene expression and secreted mature protein levels.

\section{Biosynthesis of peptides in platypus venom}

While the real targets of platypus kallikrein are still unknown, we expected that its proteolytic activity might synergistically contribute to toxicity through the specific cleavage of other venom constituents. Figure 7 summarizes a proposed biosynthesis of venom peptides. It is reasonable that OvCNP-39a is formed from a precursor, pre-OvCNP (208 amino acids), and that the $\mathrm{Leu}^{2}$ residue is partially isomerized into the D-form to give 39b [27]. Meanwhile, the N-terminal domain CNP fragment peptides 1, 3, and $\mathbf{4}$ may be formed by the specific degradation by kallikrein-like protease(s) and dipeptidyl peptidases. 


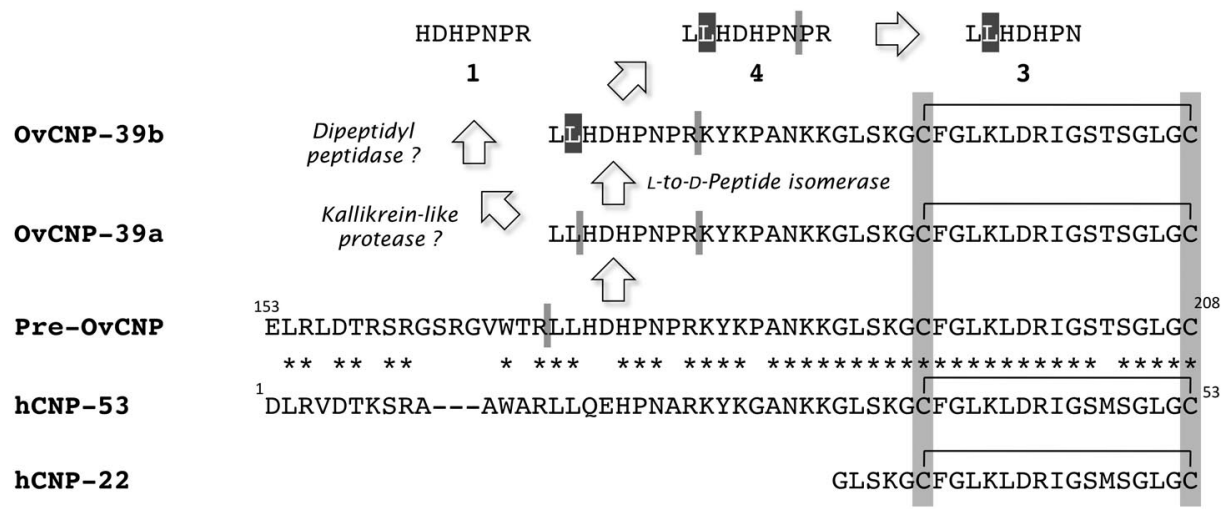

Fig. 7 Proposed biosynthesis of peptides in platypus venom. D-Leu residues are highlighted in black. Conserved cysteine residues are also highlighted. An asterisk indicates an amino acid residue that is identical between OvCNP and hCNPs.

CNPs are some of the most well characterized peptide hormones among a wide range of vertebrates. The amino acid sequences of mammalian CNPs, such as human CNPs (hCNP-53, -22) and mouse CNP, are highly conserved, and a disulfide bond between two cysteine residues in the C-terminus has been shown to be essential for their activities. However, we think that these CNPs in mammals may commonly be further degraded to give diverse physiologically active substances. If so, it is possible to find various bioactive fragment peptides that are derived not only from CNPs, but also from other well-characterized peptide hormones and proteins.

\section{CONCLUSION}

Owing to the interesting ecology of venomous mammals, we examined the constituents of platypus venom. We identified unique neurotoxic peptides and demonstrated the presence of kallikrein-like protease(s). The present findings may lead to the development of valuable vasoactive or pain-relief agents, and to a deeper understanding of the biological evolution of vertebrates in relation to toxic substances. Further studies on the target biomacromolecules of the venom constituents found in this study and on their functions that lead to neurotoxic symptoms are currently underway.

\section{EXPERIMENTAL}

\section{Venom collection}

The duckbill platypus venom project was conducted on property owned by the Zoological Parks Board of New South Wales, Australia. Platypus venom was collected from a male platypus (bodyweight $1 \sim 1.5 \mathrm{~kg}$ ) under anesthesia at the Taronga Zoo, Sydney, Australia, in October 2005 (spring, breeding season) and April 2006 (autumn). The muscles around the crural gland and venom resavoir were massaged and droplets of venom were aspirated from the tip of each spur using an Eppendorf micropippete according to the reference [24]. The collected venom (totally $\sim 15 \mu \mathrm{L}$ ), a clear viscous fluid, was immediately frozen under liquid nitrogen and then stored at $-70{ }^{\circ} \mathrm{C}$ until use.

\section{Purification of the platypus venom peptides}

Separation of the bioactive substances in platypus venom was performed as described previously [40]. In brief, $5 \mu \mathrm{L}$ of platypus venom fluids (corrected in the breeding season) were diluted 10-fold with ice- 
cold $0.1 \mathrm{M} \mathrm{NH}_{4} \mathrm{OAc}$, loaded on a TSKgel G2000SW $\mathrm{XL}_{\mathrm{X}}$ column $(7.8 \mathrm{~mm}$ I.D. $\times 300 \mathrm{~mm}$, TOSOH Co., Osaka, Japan), and eluted with $0.1 \mathrm{M} \mathrm{NH}_{4} \mathrm{OAc}$ at a flow rate of $0.2 \mathrm{~mL} / \mathrm{min}$, with monitoring at $280 \mathrm{~nm}$ at $4{ }^{\circ} \mathrm{C}$. Twenty fractions were collected from 20 to $120 \mathrm{~min}$, and every two fractions were combined to give 10 fractions, fr. I-X (Fig. 5a). 2/5 amounts of each fr. I-X were freeze-dried, dissolved in water $(100 \mu \mathrm{L})$, and freeze-dried again. This step was repeated twice to remove the remaining ammonium acetate. The lyophilized samples were subjected to cell-based $\mathrm{Ca}^{2+}$ influx assays and SDS-PAGE analysis (Fig. 5b).

$2 / 5$ amounts of fr. IX were loaded on a $\mathrm{C}_{30}$ Develosil RP-AQEUOUS AR-5 semi-micro column (1.5 mm I.D. $\times 150 \mathrm{~mm}$, Nomura Chemical Co., Aichi, Japan) at $20{ }^{\circ} \mathrm{C}$. A linear gradient of $0-25 \%$ aq. $\mathrm{MeCN}$ for $120 \mathrm{~min}$ containing $0.05 \%$ TFA was applied at a flow rate of $100 \mu \mathrm{L} / \mathrm{min}$ to give heptapeptide 1 ( $\sim 400 \mathrm{ng})$. Similarly, 1/20 amount of fr. VI was separated to give hexapeptide 2 ( $20 \mathrm{ng})$, a mixture of peptides 5-8 (total $\sim 40 \mathrm{ng}$ ), and a mixture of peptides 9-11 (total $\sim 30 \mathrm{ng}$ ), respectively. Furthermore, $1 \mu \mathrm{L}$ of the platypus venom fluid (corrected in the breeding season) was separated to give heptapeptide $3(\sim 200 \mathrm{ng})$ and nonapeptide $4(\sim 50 \mathrm{ng})$, respectively.

\section{Enzyme assay}

Enzyme activity using the Pro-Phe-Arg-MCA substrate was analyzed with a Hitachi F-4500 fluorescence spectrophotometer by measuring the amount of 4-amino-7-methyl-coumarin (AMC) released, with excitation and emission wavelengths of $370 \mathrm{~nm}$ and $460 \mathrm{~nm}$, respectively, at $37{ }^{\circ} \mathrm{C}$, as previously described [8]. One unit was defined as $1 \mu \mathrm{mol}$ of AMC released from peptidyl-MCA substrates per minute, at $37^{\circ} \mathrm{C}$.

The degradation of kininogens was measured by incubating $0.2 \mathrm{mg} / \mathrm{mL} \mathrm{LK}$ in $50 \mathrm{mM}$ Tris $\cdot \mathrm{HCl}$ buffer (pH 8.5) with platypus venom fr. II $(3.3 \mu \mathrm{L}, 2 \mathrm{mU})$ or PPK $(14 \mathrm{ng}, 2 \mathrm{mU})$ at $37^{\circ} \mathrm{C}$, with a reaction mixture volume of $20 \mu \mathrm{L}$. At $0,10,30$, and $60 \mathrm{~min}, 5 \mu \mathrm{L}$ of the reaction mixture was withdrawn and added to $5 \mu \mathrm{L}$ of denaturing solution, as previously described [8,9]. After the samples were boiled for $5 \mathrm{~min}$, SDS-PAGE was performed using a precast $10 \%$ polyacrylamide gel (ATTO Co., Tokyo, Japan), and the gels were stained with a Silver Stain Kit, Protein (Amersham). To determine the inhibition of enzymatic activity by a protease inhibitor, the platypus venom fr. II or PPK ( $0.5 \mathrm{mU}$ each) was incubated with $10 \mu \mathrm{M}$ aprotinin for $5 \mathrm{~min}$ at $37^{\circ} \mathrm{C}$ before use.

\section{In-gel digestion}

After SDS-PAGE, gels were silver-stained in a mass-compatible manner as described in the literature $[59,60]$. Stained spots were excised from a PAGE gel, and the gels were desilverized and dehydrated, and the proteins were carbamidomethylated according to the manufacturer's protocol. The gels were incubated with a sequence-grade modified trypsin [1:100 (w/w)] (\#V5111, Promega) in $25 \mathrm{mM}$ ammonium bicarbonate at $37{ }^{\circ} \mathrm{C}$ for $19 \mathrm{~h}$ as described previously [8]. The tryptic peptide mixtures were extracted from the gel and desalted using a pipette-attached tip column (Zip-Tip C18, Millipore) for MS and MS/MS analyses. MALDI-TOF MS was performed using a Bruker ultrafleXtreme spectrometer with $\alpha$-cyano-4-hydroxycinnamic acid as a matrix.

\section{ACKNOWLEDGMENTS}

I am deeply grateful to Profs. D. Black (University of New South Wales) and D. Uemura (Kanagawa University, professor emeritus at Nagoya University) for their kind guidance and encouragement regarding the platypus venom project. I am also thankful to Dr. L. Vogelnest (Taronga Zoo, Sydney, Australia) for collecting platypus venom, and to Drs. K. Yamada, O. Ohno, and Prof. H. Kigoshi for their helpful discussions. Support was provided by JSPS via Grants-in-Aid for Scientific Research (21681028 and 21651091), the Kato Memorial Bioscience Foundation, the Naito Foundation, the 
Uehara Memorial Foundation, the Japan Foundation for Applied Enzymology, and the Takeda Science Foundation.

\section{REFERENCES AND NOTES}

1. M. Pucek. In Venomous Animals and their Venoms, W. Bücherl, E. A. Buckley, V. Deulofen (Eds.), Vol. 1, pp. 43-50, Academic Press, New York (1968).

2. S. Churchfield. The Natural History of Shrews, Cornell University Press, Ithaca, NY (1990).

3. O. P. Pearson. J. Mamm. 23, 159 (1942).

4. M. J. Dufton. Pharmacol. Ther. 53, 199 (1992).

5. B. Lawrence. J. Mamm. 26, 393 (1945).

6. H. L. Babcock. Science 40, 526 (1914).

7. L. L. Getz, C. M. Larson, K. A. Lindstrom. J. Mamm. 73, 591 (1992).

8. M. Kita, Y. Nakamura, Y. Okumura, S. D. Ohdachi, Y. Oba, M. Yoshikuni, H. Kido, D. Uemura. Proc. Natl. Acad. Sci. USA 101, 7542 (2004).

9. M. Kita, Y. Okumura, S. D. Ohdachi, Y. Oba, M. Yoshikuni, Y. Nakamura, H. Kido, D. Uemura. Biol. Chem. 386, 177 (2005).

10. M. Kita. Biophilia 5, 29 (2009). (in Japanese)

11. D. Uemura, M. Kita, H. Arimoto, M. Kitamura. Pure Appl. Chem. 81, 1093 (2009).

12. D. Uemura. Proc. Jpn. Acad., Ser. B 86, 190 (2010).

13. J. H. Calaby. In Venomous Animals and their Venoms, W. Bücherl, E. A. Buckley, V. Deulofen (Eds.), Vol. 1, pp. 15-29, Academic Press, New York (1968).

14. E. A. Home. Philos. Trans. R. Soc. Lond. B 92, 67 (1802).

15. C. J. Martin, F. Tidswell. Proc. Linn. Soc. New South Wales 9, 471 (1894).

16. C. H. Kellaway, D. H. LeMesserier. J. Aust. Biol. Exp. Med. Biol. 205 (1935).

17. A. M. Torres, P. W. Kuchel. Toxicon 44, 581 (2004).

18. A. M. Torres, P. W. Kuchel. Biochemist 22, 33 (2000).

19. J. M. S. Koh, P. S. Bansal, A. M. Torres, P. W. Kuchel. Aust. J. Zool. 57, 203 (2009).

20. A. M. Torres, X. Wang, J. I. Fletcher, D. Alewood, P. F. Alewood, R. Smith, R. J. Shimpson, G. M. Nicholson, S. K. Sutherland, C. H. Gallagher, G. F. King, P. W. Kuchel. Biochem. J. 341, 785 (1999).

21. A. M. Torres, G. de Plater, M. Doverskog, L. C. Birinyi-Strachan, G. M. Nicholson, C. H. Gallagher, P. W. Kuchel. Biochem. J. 348, 649 (2000).

22. A. M. Torres, C. Tsampazi, D. P. Geraghty, P. S. Bansal, P. F. Alewood, P. W. Kuchel. Biochem. J. 391, 215 (2005).

23. C. M. Whittington, A. T. Papenfuss, P. W. Kuchel, K. Belov. Toxicon 52, 559 (2008).

24. G. de Plater, R. L. Martin, P. J. Milburn. Toxicon 33, 157 (1995).

25. G. de Plater, R. L. Martin, P. J. Milburn. Toxicon 36, 847 (1998).

26. A. M. Torres, D. Alewood, P. F. Alewood, C. H. Gallagher, P. W. Kuchel. Toxicon 40, 711 (2002).

27. A. M. Torres, M. Tsampazi, C. Tsampazi, E. C. Kennett, K. Belov, D. P. Geraghty, P. S. Bansal, P. S. Alewood, P. W. Kuchel. FEBS Lett. 580, 1587 (2006).

28. P. S. Bansal, A. M. Torres, B. Crossett, K. K. Y. Wong, J. M. S. Koh, D. P. Geraghty, J. I. Vandenberg, P. W. Kuchel. J. Biol. Chem. 283, 8969 (2008).

29. A. M. Torres, P. S. Bansal, D. Alewood, D. P. Geraghty, P. W. Kuchel. In D-Amino Acids: A New Frontier in Amino Acid and Protein Research - Practical Methods and Protocols, P. Konno, G. Fisher (Eds.), pp. 379-387, Nova Science Publishers, New York (2007).

30. A. M. Torres, M. Tsampazi, E. C. Kennett, K. Belov, D. P. Geraghty, P. S. Bansal, P. F. Alewood, P. W. Kuchel. Amino Acids 32, 63 (2006).

31. J. M. S. Koh, S. J. P. Chow, B. Crossett, P. W. Kuchel. Chem. Biodivers. 7, 1603 (2010).

32. J. M. S. Koh, L. Haynes, K. Belov, P. W. Kuchel. Aust. J. Zool. 58, 284 (2010). 
33. C. M. Whittington, A. T. Papenfuss, P. Bansal, A. M. Torres, E. S. M. Wong, J. E. Deakin, T. Graves, A. Alsop, K. Schatzkamer, C. Kremitzki, C. P. Ponting, P. Temple-Smith, W. C. Warren, P. W. Kuchel, K. Belov. Genome Res. 18, 986 (2008).

34. C. M. Whittington, J. M. S. Koh, W. C. Warren, A. T. Papenfuss, A. M. Torres, P. W. Kuchel, K. Belov. J. Proteomics 72, 155 (2009) and refs. therein.

35 M. Kita, D. Uemura. Chem. Rec. 10, 48 (2010).

36. M. Kita, O. Ohno, C. Han, D. Uemura. Chem. Rec. 10, 57 (2010).

37. M. Kita, M. Kitamura, D. Uemura. In Comprehensive Natural Products, $2^{\text {nd }}$ ed., K. Mori (Ed.), Vol. 4, Chap. 6, pp. 263-281, Elsevier, Amsterdam (2010).

38. D. Uemura. Chem. Rec. 6, 235 (2006).

39. M. Kita, D. Uemura. Chem. Lett. 34, 454 (2005).

40. M. Kita, D. StC. Black, O. Ohno, K. Yamada, H. Kigoshi, D. Uemura. J. Am. Chem. Soc. 131, 18038 (2009).

41. When we collected platypus venom fluid from living specimens, it was immediately frozen and stored at low temperature to avoid decomposition. Despite this, the venom likely contained some fragments of OvCNPs. This suggests that OvCNP or its precursors may already be degraded (at least partially) and bioactive peptides including 1 would be formed during venom secretion. We hope to verify that the CNP fragment peptides were really produced in the venom gland and that the proteolytic activity of the venom synergistically contribute to toxicity in future studies.

42. C. S. Barr, P. Rhodes, A. D. Struthers. Peptides 17, 1243 (1996).

43. J. I. Kourie. Am. J. Physiol. C43, 277 (1999).

44. G. de Plater, P. J. Milburn, R. L. Martin. J. Neurophysiol. 85, 1340 (2001).

45. J. I. Kourie. J. Physiol. 518, 359 (1999).

46. In this work, peptides 1-11 were all purified from the venom fluid collected in the breeding season. Meanwhile, we found that the venom fluid collected in the non-breeding season also contained nonapeptide 4 by the MS analysis (see ref. [11]).

47. R. Lura, V. Schirch. Biochemistry 27, 7671 (1988).

48. The concentrations of peptides 1 and $\mathbf{4}$ in the venom fluid were 230 and $46 \mu \mathrm{M}$, respectively, as estimated by reverse phase HPLC analyses. While the biological activities of $\mathbf{1}$ and $\mathbf{4}$ were relatively low, we concluded that they are actually one of the bioactive substances in the venom (see ref. [40]). We expect that these peptides may have abilities to specifically bind to the other target proteins or receptors that lead to neurotoxic symptoms.

49. While the size of crural gland is apparently changeable with season, the largest gland in breeding season was reported to be $44 \mathrm{~mm}$ long and $15 \mathrm{~mm}$ wide (see ref. [13]). This result suggests that platypus may enable to produce and secrete considerable amounts of venom fluids much more than those of manually collected by ourselves as well as by the Australian researchers (i.e., 20-80 $\mu \mathrm{L}$, see ref. [24]).

50. J. A. Clements. Endocrinol. Rev. 10, 393 (1989).

51. R. W. Colman, A. H. Schmaier. Blood 90, 3819 (1997).

52. D. Proud, A. P. Kaplan. Annu. Rev. Immunol. 6, 49 (1988).

53. R. A. Hendon, A. T. Tu. Biochemistry 20, 3517 (1981).

54. P. Utaisincharoen, S. P. Mackessy, R. A. Miller, A. T. Tu. J. Biol. Chem. 268, 21975 (1993).

55. G. Datta, A. T. Tu. J. Peptide Res. 50, 443 (1997).

56. M. Kita, H. Kigoshi, D. Uemura. Unpublished work.

57. E. S. W. Wong, A. T. Papenfuss, C. M. Whittington, W. C. Warren, K. Belov. Mol. Biol. Evol. 29, 167 (2011).

58. C. M. Whittington, A. T. Papenfuss, D. P. Locke, E. R. Mardis, R. K. Wilson, S. Abubucker, M. Mitreva, E. S. W. Wong, A. L. Hsu, P. W. Kuchel, K. Belov, W. C. Warren. Genome Biol. 11, R95 (2010).

59. A. Shevchenko, M. Wilm, O. Vorm, M. Mann. Anal. Chem. 68, 850 (1996).

(C) 2012, IUPAC

Pure Appl. Chem., Vol. 84, No. 6, pp. 1317-1328, 2012 
60. M. Kita, Y. Hirayama, M. Sugiyama, H. Kigoshi. Angew. Chem., Int. Ed. 50, 9871 (2011). 